\title{
(2) OPEN ACCESS \\ Successful management of severe acute respiratory distress syndrome due to COVID-19 with extracorporeal membrane oxygenation during mid- trimester of pregnancy
}

\author{
Zenab Yusuf Tambawala ำ , Zeinabsadat Tabatabaei Hakim, Lama Khalid Hamza, \\ Maryam Al Rayes
}

Department of Obstetrics and Gynecology, Dubai Hospital, Dubai, UAE

\section{Correspondence to}

Dr Zenab Yusuf Tambawala; drzenabtambawala@gmail.com

Accepted 20 January 2021
Check for updates

(c) BMJ Publishing Group Limited 2021. Re-use permitted under CC BY-NC. No commercial re-use. See rights and permissions. Published by BMJ.

To cite: Tambawala ZY, Hakim ZT, Hamza LK et al. BMJ Case Rep

2021;14:e240823

doi: $10.1136 /$ bcr-2020

240823

\section{SUMMARY}

A 29-year-old pregnant woman presented at 26 weeks of gestation with fever and cough for 4 days. On admission, her nasopharyngeal swab confirmed COVID-19. As her respiratory distress worsened, she was shifted to the intensive care unit (ICU). Since the patient was unable to maintain saturation even on high settings of mechanical ventilation, she underwent venovenous extracorporeal membrane oxygenation (VV-ECMO) and was monitored in surgical ICU by a multidisciplinary team. The obstetrical team was on standby to perform urgent delivery if needed. Her condition improved, and she was weaned off after 5 days on extracorporeal membrane oxygenation. She was observed in the antenatal ward for another week and discharged home with the mother and fetus in good condition. VV-ECMO can be considered as rescue therapy for pregnant women with refractory hypoxaemia of severe respiratory failure due to COVID-19. It can save two lives, the mother and fetus.

\section{BACKGROUND}

Obstetrical critical care patients are very challenging to manage. Prior to COVID-19, obstetrical patients were rarely admitted to the intensive care unit (ICU), the overall rate being 2.21 per 1000 women. ${ }^{1}$ COVID-19 has added to the morbidity and mortality of pregnant and recently delivered women. Almost 4\%-6\% of women in the childbearing age group, who are critically ill with COVID-19 and admitted to ICU, are pregnant. ${ }^{2}$ When the other treatment modalities like antiretroviral, corticosteroids, antibiotics, anti-interleukin 6 , anticoagulants or mechanical ventilation do not show significant clinical improvement, venovenous extracorporeal membrane oxygenation (VVECMO) can be considered in a small percentage of such pregnant women.

During management of pregnancy with a viable fetus (more than 24 weeks) when the maternal condition deteriorates, there is the usual inclination towards immediate delivery, both to salvage the fetus and to decrease the cardiorespiratory load of the pregnant women. However, this may not be the best option, and in certain cases especially in centres where expertise is available, other options such as VV-ECMO should be preferred rather than delivering an extremely preterm neonate. We present this case report of a patient who underwent VV-ECMO at 26 weeks of gestation and had a good recovery without significant effect on fetal growth. A small but definite portion of COVID-19 infections in pregnancy will progress to severe pneumonia and will require intensive care and extracorporeal membrane oxygenation (ECMO).

Until December 2020, our 625-bedded tertiary care multispecialty hospital has managed 120 pregnant women with COVID-19. Out of these, three women required ICU admission and ventilator support. The presented case report is of the only antenatal patient who required ECMO.

\section{CASE PRESENTATION}

A 29-year-old pregnant women presented at 26 weeks of gestation with fever and cough for 4 days to the emergency room at our tertiary care maternity hospital. This was her second pregnancy. In her previous pregnancy, 2 years ago, she had a full-term caesarean delivery. During the present pregnancy, she had regular antenatal visits. Her body mass index was $35 \mathrm{~kg} / \mathrm{m}^{2}$. Her anomaly scan at 20 weeks and glucose tolerance test at 24 weeks were normal. Her last routine antenatal visit was 2 weeks prior to the emergency admission.

On admission, her X-ray showed patchy infiltrates suggestive of pneumonia, and nasopharyngeal swab confirmed COVID-19. She was initially admitted to the isolation ward and started on prophylactic medication as per National Guidelines for Clinical Management and Treatment of COVID-19 in the United Arab Emirates. ${ }^{3}$

As her condition worsened, she was shifted to the ICU by the third day of admission. The antibiotic was changed to intravenous piperacillintazobactam. A therapeutic dose of enoxaparin was given, and she was started on continuous positive airway pressure with noninvasive high settings. As her respiratory distress worsened further, she was intubated and given mechanical ventilation (table 1).

The patient was unable to maintain saturation even on high settings of mechanical ventilation. Her pre-ECMO settings were synchronised intermittent mandatory ventilation with pressureregulated volume control with fraction of inspired oxygen $\left(\mathrm{FiO}_{2}\right) 100 \%$, respiratory rate 20, positive 
Table 1 Arterial blood gas values and ventilator settings

\begin{tabular}{|c|c|c|c|c|c|c|c|c|}
\hline$A B G$ & On shift to ICU & On CPAP & $\begin{array}{l}\text { On mechanical } \\
\text { ventilator }\end{array}$ & $\begin{array}{l}\text { Before ECMO } \\
\text { initiation }\end{array}$ & $\begin{array}{l}\text { After ECMO } \\
\text { initiation }\end{array}$ & $\begin{array}{l}\text { Day } 1 \\
\text { ECMO }\end{array}$ & $\begin{array}{l}\text { Just prior to } \\
\text { ECMO wean } \\
\text { off }\end{array}$ & $\begin{array}{l}\text { Just prior to } \\
\text { ventilator } \\
\text { wean off }\end{array}$ \\
\hline $\mathrm{PH}(7.35-7.45)$ & 7.424 & 7.432 & 7.341 & 7.554 & 7.449 & 7.364 & 7.438 & 7.418 \\
\hline $\mathrm{PCO}_{2}(35-45 \mathrm{~mm} \mathrm{Hg})$ & 30.6 & 34.6 & 49.5 & 30.4 & 39.0 & 52.9 & 40.6 & 41.2 \\
\hline $\mathrm{PO}_{2}(83-108 \mathrm{~mm} \mathrm{Hg})$ & 68.3 & 57.1 & 62.1 & 71.1 & 69.2 & 82.0 & 97.4 & 97.1 \\
\hline $\mathrm{HCO}_{3}(21-28 \mathrm{mmol} / \mathrm{L})$ & 19.7 & 22.7 & 26.0 & 26.8 & 26.6 & 29.4 & 27.0 & 26.1 \\
\hline BASE $(+)(\mathrm{mmol} / \mathrm{L})$ & 0.8 & 1.4 & 0.9 & 4.2 & 2.9 & 4.4 & 3.1 & 2.0 \\
\hline Lactic acid $(0.5-1.6 \mathrm{mmol} / \mathrm{L})$ & 1.0 & 2.0 & 1.0 & 1.1 & 1.1 & 1.0 & 0.5 & 0.9 \\
\hline \multicolumn{9}{|l|}{ Ventilator settings } \\
\hline $\mathrm{FiO}_{2}(\%)$ & 70 & 100 & 100 & 100 & 60 & 40 & 40 & 40 \\
\hline $\mathrm{PaO}_{2} / \mathrm{FiO}_{2}$ ratio & 97 & 57 & 62 & 71 & 173 & 205 & 243 & 245 \\
\hline $\mathrm{SaO}_{2}(95 \%-99 \%)$ & 93.1 & 86.6 & 86.8 & 85.0 & 92.4 & 94.0 & 97.4 & 96.2 \\
\hline PEEP $\left(\mathrm{cm} \mathrm{H}_{2} \mathrm{O}\right)$ & 5 & 6 & 15 & 15 & 18 & 9 & 9 & 5 \\
\hline
\end{tabular}

$\mathrm{ABG}$, arterial blood gas; $\mathrm{BASE}$, base excess; $\mathrm{CPAP}$, continuous positive airway pressure; $\mathrm{ECMO}$, extracorporeal membrane oxygenation; FiO ${ }_{2}$, $\mathrm{Fraction}$ of inspired oxygen; $\mathrm{HCO}_{3^{\prime}}$, bicarbonate; $\mathrm{ICU}$, intensive care unit; $\mathrm{PaO}_{2}$, partial pressure of oxygen; $\mathrm{PCO}_{2}$, partial pressure of carbon dioxide; $\mathrm{PEEP}$, positive end-expiratory pressure; $\mathrm{PH}_{1}$ potential of hydrogen; $\mathrm{PO}{ }_{2}$, partial pressure of oxygen; $\mathrm{SaO}_{2}$, oxygen saturation.

end-expiratory pressure (PEEP) $15 \mathrm{~cm} \mathrm{H}_{2} 0$, mean airway pressure 22 and tidal volume $500 \mathrm{~mL}$.

A multidisciplinary team consisting of senior intensivists, cardiothoracic surgeons, obstetricians and anaesthetists decided after a detailed discussion with the patient's family to opt for ECMO insertion. This was a crucial decision of favouring ECMO over urgent delivery of the fetus, in a critically ill pregnant woman with a viable fetus.

Midazolam (5 mg/hour) and fentanyl (300 $\mu \mathrm{g} /$ hour) on continuous flow were administered for analgesia and sedation, and cisatracurium ( $8 \mathrm{mg} /$ hour) on flow was used for the neuromuscular block. Effective anticoagulation by heparin infusion was achieved. This was confirmed with an activated partial thromboplastin time (APTT) of 53.2 seconds.

Under ultrasound guidance, using the Seldinger technique, 23 French ECMO drainage cannula was inserted in the right femoral vein, and 21 French ECMO return cannula was inserted in the right internal jugular vein. VV-ECMO circuit was initiated with a flow rate of $4.8 \mathrm{~L} / \mathrm{min}$, pump speed of $3000 \mathrm{rpm}$ and sweep rate of $4 \mathrm{~L} / \mathrm{min}$. The ECMO run was similar to that used in the non-pregnant patients. A senior obstetrician monitored the fetal heart during the process. After inserting the ECMO circuit, the patient was transferred to Dubai Hospital where ECMO facilities are better established for further management.

The patient was monitored in the surgical ICU by a multidisciplinary team of cardiothoracic surgeons, obstetricians, perfusionists, anaesthetists and intensivists. As she was about 27 weeks of gestation, daily fetal cardiotocography was done to monitor her fetus. Her repeat COVID-19 swab after 7 days was negative. The pateint's condition improved, and she was weaned off ECMO after 5 days. Postdecannulation of ECMO patient maintained haemodynamic stability without inotropic support (table 2).

The patient was monitored in the general antenatal ward for 1 week. She has regular chest physiotherapy sessions in the ward. The fetal growth parameters and Doppler Studies of the umbilical artery were found to be normal and corresponding to the period of gestation.

\section{INVESTIGATIONS}

The patient was monitored on a daily basis for white blood cell count, platelet count, arterial blood gas analysis, coagulation markers, D-dimer and septic markers. Her white blood cell count on day 1 was 8.2 (reference range: $4.5-11 \times 10^{9} / \mathrm{L}$ ), which increased to 19.9 by day 5 and decreased back to 7.4 by day 7 . Her platelet count was between 145 and 198 (reference range: $\left.150-450 \times 10^{9} / \mathrm{L}\right)$, which was essentially normal. Her D-dimer ranged from 1.03 to $1.23 \mu \mathrm{g} / \mathrm{mL}$ fibrinogen-equivalent units (FEU) (reference range: $0.1-0.45 \mu \mathrm{g} / \mathrm{mL}$ FEU), slightly higher than normal.

Blood sugar levels, liver function tests and renal function tests were also done. Cardiac markers like troponin $\mathrm{T}$ and pro-brain natriuretic peptide) were done to rule out myocardial injury. Ferritin levels were also done daily and were between 36 and 45 $\mathrm{ng} / \mathrm{mL}$ (reference range: $10-120 \mathrm{ng} / \mathrm{mL}$ ) during the first 5 days. Later, the ferritin levels increased from 76.8 to $132.9 \mathrm{ng} / \mathrm{mL}$ by day 14 of admission. Her chest X-ray findings were indicative of disease severity (figure 1). Her APTT levels (reference range: 30-40 seconds) were monitored while she was on ECMO and were maintained between 50 and 60 seconds.

\section{OUTCOME AND FOLLOW-UP}

At discharge, the pregnant woman was at 29 weeks of gestation. She was advised to taper prednisolone by $5 \mathrm{mg}$ every 5 days and enoxaparin to once a day. She had her 32week outpatient antenatal visit and is doing well. The fetal growth parameters were corresponding to the period of gestation. She is scheduled for regular antenatal follow-ups to ascertain adequate fetal growth and is planned for transthoracic echocardiography on an outpatient basis.

\section{DISCUSSION}

Acute respiratory distress in the obstetrical population due to viral pneumonia requiring ECMO during the mid-trimester of pregnancy is rare. A review of the literature showed that up until 2016, only 45 cases of ECMO in pregnancy were reported the world over, and most of these were during the H1N1 pandemic. Similar to our patient, most patients reported were in the midtrimester (26.5 weeks average) and had an average ECMO run for 12.2 days. $^{4}$ Our patient recovered in 5 days. Survival after VV-ECMO, which is most often used for respiratory failure, was $77.8 \%$ for the mother and $65 \%$ for the fetus. ${ }^{4}$

During ECMO, major haemorrhage is the most common complication. In fact, $57.1 \%$ of the women in one study needed large-volume blood transfusions. ${ }^{5}$ The sites of bleeding were 
Table 2 Timeline of patient condition and management

\begin{tabular}{|c|c|c|c|c|}
\hline Day & General condition & Respiratory support & Investigations & Management \\
\hline Day 1 & $\begin{array}{l}\text { Admitted to } \\
\text { Isolation ward }\end{array}$ & Oxygen via nasal prongs & COVID-19 PCR positive & $\begin{array}{l}\text { Budesonide, ceftriaxone } \\
\text { Methylprednisolone, enoxaparin } \\
\text { Lopinavir-ritonavir, hydroxychloroquine }\end{array}$ \\
\hline Day 3 & Shifted to ICU & $\begin{array}{l}\text { Noninvasive settings } \\
\text { CPAP }\end{array}$ & $A B G$ deteriorating & $\begin{array}{l}\text { Piperacillin-tazobactam } \\
\text { Ipratropium }\end{array}$ \\
\hline Day 4 & Fully sedated & $\begin{array}{l}\text { Severe hypoxaemia } \\
\text { IPPV }\end{array}$ & $\begin{array}{l}\text { CKMB } \\
\text { Troponin }\end{array}$ & $\begin{array}{l}\text { Multidisciplinary team review } \\
\text { Inotrope support }\end{array}$ \\
\hline Day 5 & Severe bilateral COVID-19 pneumonia & $\begin{array}{l}\text { Intubated } \\
\text { SIMV/PRVC }\end{array}$ & $\mathrm{ECHO}$ & $\begin{array}{l}\text { High-risk consent } \\
\text { Heparinised prior to ECMO } \\
\text { Cisatracurium }\end{array}$ \\
\hline Day 6 & Under general anaesthesia & VV-ECMO initiated & $\begin{array}{l}\text { Daily CTG } \\
\text { APTT levels }\end{array}$ & Transferred to Dubai Hospital \\
\hline $\begin{array}{l}\text { Day } 7 \text { to } \\
\text { day } 10\end{array}$ & Respiratory parameters improving & On ECMO & COVID-19 PCR negative & $\begin{array}{l}\text { On heparin infusion } \\
\text { Close fetal surveillance }\end{array}$ \\
\hline Day 11 & Maintaining normal oxygenation & ECMO weaning and decannulation & ABG improving & $\begin{array}{l}\text { Haemodynamically stable without inotrope } \\
\text { support }\end{array}$ \\
\hline Day 12 & Awake and communicating & Extubated & $\begin{array}{l}\text { Ferritin } \\
\text { D-dimer }\end{array}$ & Weaned off mechanical ventilator \\
\hline $\begin{array}{l}\text { Day } 15 \text { to } \\
\text { day } 22\end{array}$ & $\begin{array}{l}\text { Ambulating } \\
\text { In general ward }\end{array}$ & Maintaining saturation & Daily CTG & Haemodynamically stable \\
\hline Day 23 & Discharged home & Normal respiration & $\begin{array}{l}\text { Obstetrical Ultrasound Doppler } \\
\text { Studies }\end{array}$ & $\begin{array}{l}\text { Enoxaparin, prednisolone, pantoprazole, } \\
\text { ambroxol syrup, multivitamins }\end{array}$ \\
\hline
\end{tabular}

ABG, arterial blood gas; APTT, activated partial thromboplastin time; ARDS, acute respiratory distress syndrome; CKMB, creatine kinase muscle brain; CPAP, continuous positive airway pressure; CTG, cardiotocography; ECHO, echocardiogram; ECMO, extracorporeal membrane oxygenation; ICU, intensive care unit; IPPV, intermittent positive pressure ventilation; SIMV/PRVC, synchronised intermittent mandatory ventilation with pressure-regulated volume control; VV-ECMO, venovenous extracorporeal membrane oxygenation.

intracranial, uterine, the lungs, upper gastrointestinal and from the cannulation site. Fortunately, our patient did not manifest any significant bleeding. If major bleeding was present, it would have necessitated immediate delivery. Some other complications of ECMO in pregnancy that were reported are cannula dislodgement, haemolysis and superadded infections in the blood, urine or the lungs. ${ }^{4}$

Though VV-ECMO can be considered a rescue therapy for COVID-19-induced severe respiratory distress, significant risks of hypercoagulability and oxygenation failure are to be kept in mind. ${ }^{6}$ ECMO should be considered in the highly specialised centres only where special teams are in place for constant monitoring, especially when used for the obstetrical patient. This was previously rare, but with the COVID-19 pandemic, the number of patients requiring ECMO can increase significantly.

Another aspect to be considered is ventilator settings during VV-ECMO, and few case reports have suggested that ultraprotective ventilation strategy of maintaining a peak inspiratory pressure of less than $20 \mathrm{~cm} \mathrm{H}_{2} \mathrm{O}$ and PEEP of less than 10 $\mathrm{cm} \mathrm{H}_{2} \mathrm{O}$ can prevent ventilator-induced lung injury. Long-term and increased number of studies will be required to determine the appropriate approach.

Muscle paralysis and prone position are an integral part of the protocol for a patient with acute severe respiratory distress in ICU; our patient was put in the prone position when initially admitted to the ICU, but as her condition worsened very quickly, she had to be initiated on ECMO. Prone position can be used during pregnancy in even advanced gestations with adequate support to the gravid uterus to improve ventilation. ${ }^{8}$

Methylprednisolone $40 \mathrm{mg}$ intravenous, two times per day, was given for COVID-19 pneumonitis. After weaning from ECMO therapy, she was continued on oral prednisolone $30 \mathrm{mg}$ daily, which was tapered gradually. We prefer to use intramuscular betamethasone for fetal lung maturity, but since we had

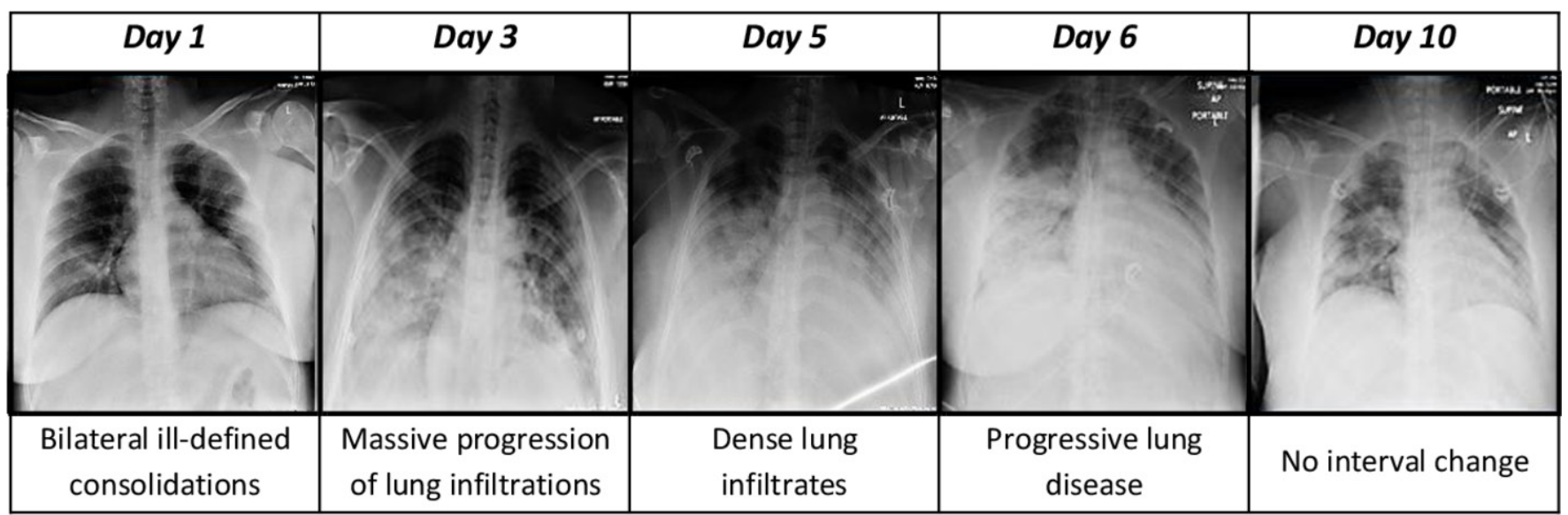

Figure 1 Chest X-ray findings. 


\section{Patient's perspective}

I realise that my baby and I am very lucky in comparison to so many others who have not been able to survive this Corona virus pandemic. I hope to deliver my baby on the due date without any more setbacks. Really grateful.

\section{Learning points}

- Venovenous extracorporeal membrane oxygenation is a feasible option for pregnant women with refractory hypoxaemia due to COVID-19 pneumonia when all else seems to have failed.

- Multidisciplinary team consisting of obstetricians, intensivists, cardiothoracic surgeons, perfusionists, anaesthetists, neonatologists, physiotherapists and nurses needs to work in close coordination to provide optimum care.

- Appropriate counselling and clear communication with relatives are needed, as the lives of both the mother and unborn child are at stake.

- Long-term outcome of both mothers and fetuses needs to be followed.

decided for ECMO and not to deliver the preterm fetus, we did not consider steroid for fetal lung maturity or magnesium for neuroprotection (which we would have if we had planned for delivery).

Anticoagulation with enoxaparin was started as a part of management of critically ill pregnant patient with high BMI, which was followed by heparin infusion during the ECMO run. She continued on enoxaparin after weaning off ECMO. There are many novel techniques of ECMO, where anticoagulation can be used minimally or avoided completely. ${ }^{9}$ This was our first case of COVID-19 and ECMO in an antenatal patient; hence, we chose to go with anticoagulation protocol.

There is inadequate data about the safety of ECMO in pregnancy, although it is a life-saving rescue therapy for acute refractory hypoxaemia mostly due to viral pneumonia, either H1N1 (influenza A virus subtype H1N1), Middle East respiratory syndrome or COVID-19. In a ten-year study of ECMO in pregnancy, only $60 \%$ of mothers and fetuses survived. ${ }^{10}$ Long-term follow-up of our patient and detailed evaluation of future cases can help evaluate efficacy and safety of ECMO in pregnancy.

We intend to follow our mother and her baby to analyse any long-term effects of VV-ECMO during the mid-trimester of pregnancy on both.
Acknowledgements We would like to acknowledge all physicians, nursing and paramedical staff involved in taking care of this patient. Appreciate Dr Obaid AlJassim, Pradeep Kumar Pillai, Suresh Babu Robert and others for the ECMO run.

Contributors ZYT: design, draft and revision of the manuscript. ZTH: data acquisition. LKH: clinical care, conceptualisation and proof-reading. MAR: conceptualisation and proof-reading. Final version for publication was agreed upon by all authors.

Funding The authors have not declared a specific grant for this research from any funding agency in the public, commercial or not-for-profit sectors.

Competing interests None declared.

Patient consent for publication Obtained.

Provenance and peer review Not commissioned; externally peer reviewed.

Open access This is an open access article distributed in accordance with the Creative Commons Attribution Non Commercial (CC BY-NC 4.0) license, which permits others to distribute, remix, adapt, build upon this work non-commercially, and license their derivative works on different terms, provided the original work is properly cited and the use is non-commercial. See: http://creativecommons.org/ licenses/by-nc/4.0/.

\section{ORCID iD}

Zenab Yusuf Tambawala http://orcid.org/0000-0002-5289-5884

\section{REFERENCES}

1 Jardine J, NMPA Project Team. Maternity admissions to intensive care in England, Wales and Scotland in 2015/16: a report from the National maternity and perinatal audit. London: RCOG, 2019. Available: https://maternityaudit.org.uk/FilesUploaded/ NMPA $\% 20$ Intensive $\% 20$ Care $\% 20$ sprint $\% 20$ report.pdf [Accessed cited 08 May 2020].

2 Lambert J, Litchfield K. Love C.COVID-19 position statement: Maternal critical care provision. SIGN evidence based clinical guidelines. Coronavirus (COVID-19): guidance on treating patients Guidance from the Chief Medical Officer (CMO) Approved date: 18/05/2020,Publication date: 19/05/2020,Version number: 1.0. Available: https:// www.sign.ac.uk/media/1633

3 Version 3.1 United Arab Emirates ministry of health and prevention. National guidelines for clinical management and treatment of COVID-19, 2020. Available: https://www.mohap.gov.ae

4 Moore SA, Dietl CA, Coleman DM. Extracorporeal life support during pregnancy. J Thorac Cardiovasc Surg 2016;151:1154-60.

5 Nair P, Davies AR, Beca J, et al. Extracorporeal membrane oxygenation for severe ARDS in pregnant and postpartum women during the 2009 H1N1 pandemic. Intensive Care Med 2011;37:648-54

6 Ahmadi ZH, Jahangirifard A, Farzanegan B. Extracorporeal membrane oxygenation and COVID-19: the causes of failure. J Card Surg 2020:1-6.

7 Park MH, Kim AJ, Lee M-J, et al. Case report of patients with acute respiratory distress syndrome caused by COVID-19: successfully treated by venovenous extracorporeal membrane oxygenation and an Ultra-Protective ventilation. Medicina 2020;56:570.

8 Ray BR, Trikha A. Prone position ventilation in pregnancy: concerns and evidence. J Obstet Anaesth Crit Care 2018:8:7-9 https://DOI:10.4103/joacc.JOACC_17_18

9 Sklar MC, Sy E, Lequier L, et al. Anticoagulation practices during venovenous extracorporeal membrane oxygenation for respiratory failure. A systematic review. Ann Am Thorac Soc 2016;13:2242-50.

10 Webster CM, Smith KA, Manuck TA. Extracorporeal membrane oxygenation in pregnant and postpartum women: a ten-year case series. Am J Obstet Gynecol MFM 2020;2:100108.

Copyright 2021 BMJ Publishing Group. All rights reserved. For permission to reuse any of this content visit

https://www.bmj.com/company/products-services/rights-and-licensing/permissions/

BMJ Case Report Fellows may re-use this article for personal use and teaching without any further permission.

Become a Fellow of BMJ Case Reports today and you can:

- Submit as many cases as you like

- Enjoy fast sympathetic peer review and rapid publication of accepted articles

- Access all the published articles

- Re-use any of the published material for personal use and teaching without further permission

Customer Service

If you have any further queries about your subscription, please contact our customer services team on +44 (0) 2071111105 or via email at support@bmj.com.

Visit casereports.bmj.com for more articles like this and to become a Fellow 